\title{
PENDEKATAN WACANA KRITIK KARAKTER SASTRAWAN KOTA MEDAN MELALUI KARYA SASTRA "PUISI”
}

\author{
Oleh: \\ Lili Herawati Parapat ${ }^{1}$ \& Eli Marlina Harahap ${ }^{2}$ \\ lili.herawati@um-taspsel.ac.id ${ }^{1}$ \& eli.marlina@um-tapsel.ac.id ${ }^{2}$ \\ Dosen Program Studi Pendidikan Bahasa dan Sastra Indonesia FKIP UMTS ${ }^{1 \& 2}$
}

\begin{abstract}
ABSTRAK
Kritik sastra merupakan studi tentang keilmuan yang berupaya memberikan \& menentukan nilai hakiki suatu karya sastra dalam bentuk memberi pujian, menyatakan kesalahan, memberikan pertimbangan pemahaman deskriftif, pendefinisian, penggolongan, penguaraian atau analisis penafsiaran, dan penilain sastra secara sistematis dan terpola dengan metode tertentu. Dalam hal ini peneliti membahasa pendekatan wacana kritik karakter sastrawan (Shafwan hadi Umry) melalui karya sastra "puisi”. Metode yang digunakan adalah analisis deskriftip kualitatif. Dalam hal ini teknik pengumpulan data yng digunakan peneliti adalah dengan wawancara langsung dengan sastrawan dan menganalisis hasil karya Umry yang salah satunya berjudul "Do’a”. Do’a ini merupakan ungkapan perasaan yang secara tegas di tuliskan isi tentang perjalanan dan kisah hidup, serta keyakinan. Sehabis kisah, aku tak tahu dimana tamatnya adalah kalimat pertama puisi dan Doa sampai di atas makrifat kalimat terakhir puisi. Puisi ini bisa dijadikan sebagai bahan pembelajaran. Karena penggunaan diksi yang bagus dan isi yang jelas mudah dipahami.
\end{abstract}

Kata kunci: Pendekatan Wacana Kritik, Karakter Sastrawan, Karya Sastra “Puisi”.

\section{Pendahuluan}

Kritik sastra yang sesungguhnya

bukan hanya menilai saja, melainkan masih ada aktivitas kritikus yakni menganalisis karya tersebut. Sebagaimana yang diungkapkann oleh Abrams bahwa kritik sastra adalah studi yang berhubungan dengan pendefinisian,

penggolongan/pengkelasan, penguraian atau analisis, dan penilaian atau evaluasi. Kritik sastra adalah salah satu jenis esai, yaitu pertimbangan baik atau buruk suatu hasil kesustaeraan. Perkembangan itu tentu dengan memberikan alasan mengenai isi dan bentuk hasil kesusasteraan. Kritik sastra merupakan studi sastra yang langsung berhadapan dengan karya sastra, secara langsung membicarakan karya sastra dengan penekanan pada penilaian (renewelek dalam suratno dkk, 2010 : 14). Karakter pada dasarnya merupakan sikap, watak dan tingkah laku manusia yang terlihat dan 
tergambar dari kepribadian manusia. Scerenco (Samawi dan Hariyanto, 2011:42) mendefinisikan karakter sebagai atribut atau ciri-ciri yang membentuk dan membedakan ciri pribadi, ciri etis dan kompleksitas mental dari seseorang atau suatu kelompok, atau bangsa. Kemendiknas (2010) dalam Sugandi dan Yusuf menjelaskan bahwa karakter adalah "watak, tabiat, akhlak, atau kepribadian seseorang terbentuk dari hasil internalisasi berbagai kebijakan (vistues) yang diyakini dan digunakan sebagai landasan untuk cara pandang, berfikir, bersikap, dan bertindak. Kebijakan terdiri atas sejumlah nilai, moral, dan norma, seperti jujur, berani bertindak, dapat dipercaya, hormat kepada orang lain. Berdasarkan pendapat sebelumnya maka dapat disimpulkan bahwa karakter adalah sifat, watak kepribadian seorang yang di yakini sebagai landasan untuk cara pandang, berpikir, bertindak dan bersikap sesorang, sehingga kepribadian masing-masing orang tergambarkan karakternya.

Seorang pencipta atau sastrawan akan melukiskan karya-karyanya sesuai dengan karakter kepribadian masing-masing pengarang. Dapat dikatakan seorang sastrawan merupakan salah seorang yang memiliki keahlian untuk mencipta karya sastra. Seorang sastrawan yang ahli merupakan sastrawan yang mampu menghipnotis pembaca melalui karyakaryanya. Hasil karya sastra seorang sastrawan merupakan suatu hasil seni yang memiliki keindahan tersendiri.

Penelitian dalam dunia pendidikan yang sering diteliti adalah tentang hasil karya sastra seperti puisi, cerpen, novel dan karya-karya lainnya. Namun sangat jarang di temukan penelitian yang membahas langsung penciptanya dan mengkritiki langsung hasil karya sastrawan.

Mengkritiki hasil karya puisi sastrawan bukanlah hal yang salah ataupun hal yang mudah. Disamping melihat penggunaan diksi yang paling penting dilihat adalah nilai-nilai yang tersirat dan tersurat dalam puisi. Apakah mengandung sarak atau tidak. Nilai-nilai yang terdapat dalam karya sastra dapat dijadikan sebagai pembelajaran dalam pengajaran sastra. serta nilai seni yang terdapat dalam sastra juga merupakan tingkah laku atau bisa saja digambarkan dari kehidupan manusia. Dalam penelitian ini yang sangat perlu diperhatikan adalah menganalisis karakter sastrawan dalam menulis puisi melalui pendekatan wacana kritik. karena pentingnya pengetahuan tentang karakter sastrawan akan mempermudah pembaca dalam memahami makna hasil karya sastra 
dan mempermudah mempelajari karya sastra dalam pengayaan pembelajaran sastra.

\section{Pembahasan}

Istilah "kritik" (sastra) berasal dari bahasa Yunani yaitu krites yang berarti "hakim". Krites sendiri berasal dari krinein "menghakimi”; kriterion yang berarti "dasar penghakiman" dan kritikos berarti "hakim kasustraan”. Pengertian kritik sastra di atas tidaklah mutlak ketetapannya, karena sampai saat ini, belum ada kesepakatan atau kepastian secara universal tentang pengertian sastra. Pada dasarnya kritik sastra merupakan kegiatan atau perbuatan mencari serta menentukan nilai hakiki karya sastra lewat pemahaman dan penafsiran sistematik yang dinyatakan kritikus dalam bentuk tertulis. Kritik sastra adalah ilmu sastra untuk menghakimi karya sastra dengan memberi penilaian, dan memutuskan apakah karya tersebut bermutu atau tidak bermutu yang sedang dikritik.

Kritik sastra yang sesungguhnya bukan hanya menilai saja, melainkan masih ada aktivitas kritikus yakni menganalisis karya tersebut. Sebagaimana yang diungkapkann oleh Abrams bahwa kritik sastra adalah studi yang berhubungan dengan pendefinisian, penggolongan/pengkelasan, penguraian atau analisis, dan penilaian atau evaluasi. Kritik sastra adalah salah satu jenis esai, yaitu pertimbangan baik atau buruk suatu hasil kesustaeraan. Perkembangan itu tentu dengan memberikan alasan mengenai isi dan bentuk hasil kesusasteraan. Kritik sastra merupakan studi sastra yang langsung berhadapan dengan karya sastra, secara langsung membicarakan karya sastra dengan penekanan pada penilaian (renewelek dalam suratno dkk, 2010 : 14). Sedangkan menurut Suratno dkk (2010 : 15) mengatakan bahwa kritik sastra adalah studi tentang keilmuan yang berupaya menentukan nilai hakiki suatu karya sastra dalam bentuk memberi pujian, menyatakan kesalahan, memberikan pertimbangan pemahaman deskriftif, pendefinisian, penggolongan, penguaraian atau analisis penafsiaran, dan penilain sastra secara sistematis dan terpola dengan metode tertentu.

Semi (Suratno dkk (2010 : 15) mengatakan ada tiga fungsi kritik sastra yaitu : (1) Untuk pembinaan dan pengembangan sastra, (2) Untuk pembinaan dan pengembangan kebudayaan, dan apresiasi seni, (3) Untuk menunjang ilmu sastra. Kemudian kritik sastra juga dapat dinilai dari dua aspek yatu estetika, sosial. Kritik sastra yang dilakukan dengan memperhatikan kaidah-kaidah-kaidah 
keindahan atau pendekatan estetika. Dalam kritik sastra ini berusaha menggunakan niali-niali keindahan karya sastra. Karena estetika merupakan suatu nilai keindahan, atau memiliki keindahan. Nilai estetika mampu memberikan hiburan, kepuasan, kenikmatan dan kebahagiaan batin ketika karya sastra dibaca atau didengar. Kritik sastra yang dilakukan dengan menggunakan pendekatan sosial. Dasar kritik sastra sosial ini adalah karya sastra itu bukan jatuh dari langit, melainkan diciptakan oleh sastrawan untuk dinikmati, dipahami, dan dimanfaatkan oleh masyarakat. Nilai sosial karya sastra sangat berhubungan erat dengan nilai sosial dalam masyarakat. Kritik sosial ini dikembngkan dari teori plato tentang dunia ide dan tiruannya dalam memahami karya sastra.

Karakter merupakan suatu tabiat, sikap karakter dan kepribadian seseorang yang dapat terlihat dari karakter seseorang. Secara umum, karakter dimaknai sebagai cara berpikir dan berprilaku yang khas tiap individu untuk hidup dan bekerja sama, baik dalam lingkup keluarga, masyarakat, bangsa dan negara. Scerenco (Samani dan Hariyanto, 2012:42) mendefinisikan karakter sebagai atribut atau ciri-ciri yang membentuk dan membedakan ciri pribadi, ciri etis dan kompleksitas mental dari seseorang atau suatu kelompok, atau bangsa. Samani dan Hariyanto (2012:43) mendefinisikan karakter sebagai nilai dasar yang membangun pribadi seseorang, terbentuk baik karena pengaruh hereditas maupun pengaruh lingkungan, yang membedakannya dengan orang lain, serta diwujudkan dalam sikap dan prilakunya dalam kehidupan sehari-hari.

Pengertian tersebut menekankan dua hal, yakni karakter menjadi pembeda seseorang dengan orang lain,dan karakter diimplementasikan dalam kehidupan seharihari. Dalam Kamus Besar Bahasa Indonesia (2008:682) karakter bermakna sebagai tabiat, sifat-sifat kejiwaan, akhlak atau budi pekerti yang membedakan seseorang dengan orang lain, watak sementara berkarakter diterjemahkan sebagai mempunyai tabiat atau mempunyai kepribadian.

Pusat kurikulum dalam Pemerintahan Indonesia (Yaumi, 2014:136) merumuskan nilai-nilai pembentukan karakter adalah: religious, jujur, torelan, disiplin, kerja keras, kreatif, madiri, demokratis, rasa ingin tahu, kebangsaan, menghargai prestasi, komunikatif, cinta damai, gemar membaca, peduli lingkungan peduli sosial, berfikir logis, dan tanggungjawab. Untuk lebih jelasnya dapat dilihat dari pembahasan berikut ini: 
1. Religious, merupakan sikap dan prilaku yang patuh dalam melaksanakan ajaran agama yang dianutnya, toleran terhadap pelakasanaan ibadah agama lain dan rukun dengan pemeluk agama lainnnya.

2. Jujur, dalam berprilaku dan didasarkan pada upaya menjadikan dirinya sebagai orang yang slalu dapat dipercaya dalam perkataan, tindakan, dan pekerjaan.

3. Torelan, merupakan sikap dan tindakan yang menghargai perbedaan agama, suku, etnis, pendapat, sikap, dan tindakan orang lain yang berbedadari dirinya.

4. Disiplin, merupakan tindakan yang menunjukkan prilaku tertib dan patuh pada berbagai ketentuan dan peraturan.

5. Kerja keras, merupakan prilaku yang mennunjukikan upaya sungguh-sungguh dalam mengatasi berbagai hambatan belajar dan tugas, serta menyelesaikan tugas dnegan sebaik-baiknya.

6. Kreatif, merupakan berfikir dan melakukan sesuatu untuk menghasilkan cara atau hasil baru dari sesuatu yyang telah dimiliki.

7. Madiri, merupakan sikap dan prilaku yang tidak mudah tergantung pada orang lain dalam menyelesaikan tugastugasnya.
8. Demokratis, merupakan cara berfikir, sikap, dan bertindak yang menilai sama hak dan kewajiban dirinya dan orang lain.

9. Rasa ingin tahu, merupakan sikap dan tindakan yang selalu berupaya untuk mengetahui lebih mendalam dan meluas dari sesuatu yang dipelajarinya, dilihat, dan didengar.

10. Kebangsaan, merupakan cara berfikir dan bertindak, dan berwawasan yang menempatkan kepentingan bangsa dan Negara di atas kepentingan diri dan kelompoknya.

11. Menghargai prestasi, merupakan cara berfikir, bersikap dan berbuat yang menunjukkan kesetiaan, kepedulian, dan penghargaan yang tinggi terhadap bahasa, lingkungan fisik, sosial, budaya, ekonomi dan politik bangsa.

12. Komunikatif, merupakan tindakan yang memperlihatkan rasa senang berbicara, bergaul, dan bekerja sama dengan oranng lain

13. Cinta damai, merupakan sikap perkataan, dan tindakan yang menyebabkan orang lain merasa senang dan aman atas kehadiran dirinya.

14. Gemar membaca, merupakan kebiasaan menyediakan waktu untuk membaca 
berbagai bacaan yang memberikan kebajikan bagi dirinya.

15. Peduli lingkungan merupakan sikap dan tindakan yang selalu berupaya mencegah kerusakan pada lingkungan alam sekitarnya, dan mengembangkan upaya-upaya untuk memperbaiki kerusakan alam yang sudah terjadi.

16. Peduli sosial, merupakan sikap dan tindakan yang selalu ingin memberikan bantuan pada orang lain dan masyarakat yang membutuhkan

17. Berfikir logis, merupakan cara berpikir secara jelas dan tegas.

18. Tanggungjawab. Merupakan sikap dan prilaku seseorang untuk melaksasnakan tugas dan kewajibannya yang seharusnya dia lakukan, terhadap diri sendiri, masyarakat, lingkungan, Negara, dan Tuhan Ynag Maha Esa.

Berdasarkan beberapa karakter tersebut dapat disimpulkan bahwa karakter sastrawan juga tidak terlepas dari beberapa karakter yang sudah dijelaskan. Sehingga dari setiap karya penciptanya/ahli sastra dapat diketahui karakter masing-masing sastrawan.

\section{Pengertian Sastrawan}

Sastrawan merupakan seorang pencipta yang dianggap ahli dalam hal sastra. Tidak hanya dipandang dari ISSN 2541-3775 banyaknya hasil karyanya. Karyanya dianggap memiliki makna yang mengisnpirasi yang tidak terlepas dari karakter penciptanya. Menurut kamus Besar Bahasa Indonesia Dalam kamus Daring menjelaskan bahwa sastrawan adalah pujangga, ahli sastra, atau pengarang prosa. Horace (Sujoko, 2016: 16) menyatakan bahwa “ seniman harus bertugas untuk docere dan delectare member ajaran dan kenikmatan, sering kali ditambah dengan movere, menggerakkan pembaca ke kegiatan yang bertanggung jawab, seni harus menggabungkan sifat utile dan dulce, bermanfaat dan memiliki nilai seni.

Boulton, dalam Siswanto (2012: 144) menjelaskan bahwa cara sastrawan menggambarkan atau memunculkan tokohnya dapat menempuh berbagai cara. Mungkin sastrawan menggambarkan tokoh seperti dalam hidup dalam mimpi, pelaku yang memiliki cara yang sesuai dengan kehidupan manusia sebanarnya atau pelaku yang egois, kacau dan mementingkan diri sendiri. Siswanto (2012: 144) menjeskan bahwa orang yang bertanggung jawab terhadan karya sastranya, karena dialah yang menulisnya. Darma dalam Siswanto (2012: 43) menjelaskan bahwa seorang penulis yang baik (satrawan) sebelum menulis harus mempunyai imajinasi, kepekaan, otak,

Vol.3 No.1 Januari - Juni 2018/51 
insting, persepsi kepengarangan, jujur, kreatif, intuisi, bakat, bekerja keras, intelektual dan hidup baik, ajeg, pecinta sastra, serta mempunyai daya serap.

Menurut Wellek dan Warren (20014: 97) ada hal yang harus diperhatikan. Hal itu adalah 1) jika seorang pengarang berhasil membuat tokoh-tokohnya berlaku sesuai dengan "kebenaran psikologis", perlu dipertanyakan apakah kebenaran semacam itu bernilai artistik atau tidak. Sebab banyak karya besar yang menyimpang dari standar psikologi sezaman atau sesudahnya. 2) Karya sastra kadang menyajikan situasisituasi yang terkadang tidak masuk akal dan motif-motif yang fantastis, dan bahkan upaya mendramatisasi cukup dominan kehadirannya. 3) Pada kasus-kasus tertentu memang pemikiran psikologi menambah keartistikan karena menunjang koherensi dan kompleksitas karya, tetapi pemikiran psikologi dalam karya sastra tidak hanya dicapai melalui pengetahuan psikologi saja.

Berdasarkan beberapa pendapat di atas maka dapat disimpulkan bahwa seorang penulis atau sastrawan adalah orang mempunyai imajinasi, kepekaan, persepsi kepengarangan, jujur, kreatif, intelaktual, pencipta sastra dan memiliki daya serap yang kuat.

\section{Metode Penelitian}

ISSN 2541-3775
Desain penelitian yang digunakan penulis dalam penelitian ini adalah dengan menggunakan metode deskriftip atau disebut dengan metode deskriftip kualitatif. Selanjutnya data penelitian diambil dari hasil karya sastrawan yang berbentuk puisi dan diambil dari wawancara langsung dengan Sastrawan kota Medan yang berjumlah 1 orang Satrawan. Sedangkan Sumber data diambil dari Satrawan Medan, yaitu: Shafwan Hadi Umry. Teknik pengumpulan data dalam penelitian ini adalah: 1) Peneliti mewancarai langsung narasumber atau Objek penelitiannya. 2) Peneliti mengumpulkan sejumlah karya sastra sastrawan yang berbentuk puisi dan menganalisis salah satu karya puisi sastrawan. 3) engenalisis hasil wawancara dengan menyesuaikannya dengan karakter manusia yang telah dipaparkan pada BAB Pembahasan materi. 4) Menyimpulkan dan mendeskripsikan karakter sastrawan kota Medan.

Adapun teknik analisis data yang digunakan dalam penelitian ini adalah Puisi karya sastrawan Shafwan Hadi Umry di anasilis secara keseluruhandan menyimpulkan hasil penelitian dalam bentuk analisis deskriftip kualitatif.

\section{Hasil Penelitian}

Vol.3 No.1 Januari - Juni 2018/52 
Shafwan hadi Umry merupakan satu sastrawan yang memiliki banyak hasil karya, baik sastra ataupun buku pembelajaran lainnya. salah satunya adalah Shafwan Hadi Umry. Maka dalam hal ini dapat di deskripsikan hasil analisis pembahasan puisi yang di sukai oleh sastrawan.

\section{Do'a}

Sehabis kisah, aku tak tahu dimana tamatnya

Sehabis hujan, aku tak tahu dimana tumpahnya

Sehabis ombak, aku tak tahu di mana hempasnya

Sehabis jalan, aku tak tahu di mana khatamnya

Sehabis kisah sehabis hujan

Sehabis ombak sehabis jalan

Sehabis ayat sehabis tamat

Doa sampai di atas makrifat.

Berdasarkan puisi Do'a di atas

dapat dipahami bahawa perjalanan dan perjuangan yang benar-benar di lalui begitu banyak dan proses yang panjang akan sampai pada akhirnya. Ketika berada pada titik harapan dan keinginan telah sampai, maka kata pun tidak akan terucap dengan sebatas tulisan. Karena sudah terlukis dalam hati dan keikhlasan.

\section{Hasil karya puisi Umry ini} merupakan ungkapan perasaan yang secara tegas di tuliskan isi tentang perjalanan dan kisah hidup, kemudian membahas tentang keyakinan. Puisi ini cocok dijadikan sebagai bahan pembelajaran. Disamping penggunaan diksi yang bagus, namun tidak mengurangi pola pikir pemahaman pembaca dalam memahami isi. Pada dasarnya memang ketika membaca di awal bait puisi, sastrawan berusaha untuk mengungkapkan perasaan tentang kelalaian dan ketidaktahuan ujung perjalanan dan cerita hidupnya. Namun diakhir bait secara tengas menyebutkan bahwa pada akhirnya tersampaikan dalam Doa sampai di atas makrifat. Berdasarkan hasil penelitian yang telah di laksanakan maka dapat disimpulkan bahwa karakter Shafwan hadi Umry termasuk pada kategori religi. Karakter religi merupakan suatu karakter yang membahasa tentang keagamaan. Sesuai dengan teori yang ada pada Pusat kurikulum dalam Pemerintahan Indonesia (Yaumi, 2014:136) yang menjelaskan bahwa religi, merupakan sikap dan prilaku yang patuh dalam melaksanakan ajaran agama yang dianutnya, toleran terhadap pelakasanaan ibadah agama lain dan rukun dengan pemeluk agama lainnnya.

\section{DAFTAR PUSTAKA}

Samawi dan Hariyanto. 2011. Konsep dan Model Pendidikan Karakter. Bandung: PT. remaja Rosdakarya.

Siswanto, Wahyudi. 2012. Pengantar Teori Sastra. Jakarta: Gramedia.

Vol.3 No.1 Januari - Juni 2018/53 
Sujoko. 2016. Unsur Buadaya Karakter Tokoh Dalam Novel Gajah Mada Sumpah di Manguntu Karya Langit Kresna Hariadi. Jurnal Pembelajaran Bahasa dan Satsra Indonesia, Volume 6, No. 1, Tahun 2016.

Tindaon, Yosi Abdian. 2016. Pembelajaran Sastra Sebagai Salah Satu Wujud Implementasi Pendidikan Berkarakter. Tersedia on line.

Wellek, Rene \& Austin Warren. Theory of Literature. Terjemahan Melani Budianta. Jakarta: Gramedia, 2014

Yaumi, Muhammad. 2011. Pendidikan Karakter. Jakarta: Kencana.

Alamat Internet:

http://kbbi.web.id/sastrawan di akses kamis, 15 Juni 2017. 